\title{
IDENTIDADES VIRTUAIS, PENSAMENTO HISTÓRICO E VIDA PRÁTICA
}

\author{
Wilian Carlos Cipriani Barom*
}

\begin{abstract}
RESUMO: O presente texto busca testar três estereótipos sociais que rondam as discussões políticas e culturais da atualidade em espaços virtuais como Facebook, Twitter e Instagram, a partir de uma proposta metodológica de correlação de ideias históricas. Estes estereótipos, aqui denominados instrumentalmente de Nacionalistas, Individualistas-conservadores e Defensores da Família, tiveram as suas características aproximadas às respostas de 3923 jovens estudantes, de 24 cidades brasileiras, que participaram do Projeto Residente no ano de 2019. Utilizando o Software SPSS Statistics-IBM e sua técnica de tabulação cruzada, buscou-se identificar e testar a presença destes três perfis nos dados da amostra.

PALAVRAS-CHAVE: Identidades virtuais; Metodologia quantitativa; Ideias históricas; Didática da história.
\end{abstract}

\section{Virtual identities, historical thinking and practical life}

ABSTRACT: This paper intends to test three social stereotypes that are currently used in the political quarrels in virtual spaces such as Facebook, Twitter and Instagram, from a correlation of historical ideas standpoint. The presence of these predetermined stereotypes, called here instrumentally as Nationalists, Individualist-conservatives and Defenders of the Family, were tested on the answers of 3923 young students, of 24 Brazilian cities, that had participated of the Resident Project in the year of 2019. We used the SPSS Statistics - IBM Software for data cross-tabulation, the presence of these three profiles in the sample data was identified and tested.

KEYWORDS: Virtual identities; Quantitative methodology; Historical ideas; Didactics of history.

\section{Identidades virtuales, pensamiento histórico y vida práctica}

RESUMEN: Este texto busca poner a prueba tres estereotipos sociales que se constituyen como espacios políticos y culturales actuales en redes virtuales como Facebook, Twitter e Instagram, a partir de una propuesta metodológica para la correlación de ideas históricas. Estos estereotipos, aquí instrumentalmente denominados Nacionalistas, Individualistas-Conservadores y Defensores de la Familia, tuvieron como características aproximadas las respuestas de 3923 jóvenes estudiantes de 24 ciudades brasileñas, que participaron en el Proyecto Residente en 2019. Utilizando el Software de Estadística SPSS - IBM y su técnica de tabulación cruzada, se identificó y probó la presencia de estos tres perfiles en los datos de la muestra.

PALABRAS CLAVE: identidades Virtuales; Metodología cuantitativa; Ideas históricas; Didáctica de la historia.

\footnotetext{
* Doutor em Educação pela Universidade Estadual de Ponta Grossa. Atualmente é professor no Departamento de História da mesma universidade. Contato: Praça Santos Andrade, 01, Centro, CEP: 84010-330, Ponta GrossaPR, Brasil. E-mail: wborientacoes@ gmail.com. ORCID: https://orcid.org/0000-0002-8230-0845
} 
Na grande mídia, e principalmente nos espaços público/privados das mídias sociais, os conteúdos históricos vêm sendo cotidianamente disputados por sujeitos, grupos e partidos políticos a partir de contornos cada vez mais autoritários. Nestas batalhas, os conhecimentos históricos que são reivindicados pleiteiam o estatuto público da verdade e são instrumentalizados como meio de fundamentação, justificativa e/ou contra-argumento nos debates, que podem ir de assuntos relacionados à política, cultura, arte, sexualidade, religião e sociedade.

Nestes espaços, graças à recente natureza algorítmica das redes sociais e a sua capacidade de retroalimentar seus públicos consumidores, visualiza-se o início de um fenômeno perturbador à sociedade que pode ser a acelerada fundamentalização das noções de moralidade, crenças, saberes e ideologias políticas. Esta aproximação entre indivíduos e interesses (que ao mesmo tempo reparte e isola a sociedade em nichos) constrói, como consequência, sujeitos avatares que estariam habitando espaços de mesma cosmovisão, num processo diário de fabricação de uma alteridade negativa, o que colabora no adensamento e reforço social de estereótipos já existentes que podem estar profundamente descolados da realidade.

Assim, em alguma medida, este fenômeno está aparentemente aprisionando os sujeitos em leituras essencialistas, uma vez que desloca as suas experiências de aprendizado dos espaços humanos de interação, passíveis de argumentos contraditórios e de vivências de sensibilidades, para um front imaginário das timelines onde se operam concepções exógenas e noção prévias "naturalmente" opostas. Ao redor de um posicionamento, ou de uma identidade social, se articulam politicamente uma infinidade de memórias que compõem as características das ações e pensamentos destes sujeitos representados. Assim, "ser" de esquerda, de direita, conservador, progressista, religioso, ateu, feminista, militar, político, indígena, professor ou militante são noções que hoje se tornaram tão problemáticas em suas definições, graças a esse plus das redes sociais, que para se ter uma definição no mínimo coerente precisa primeiro desconstruir uma infinidade de pseudo verdades que parasitam estas identificações no imaginário popular. Com essas inúmeras representações que se somam, seria como se estas identidades formassem blocos sólidos de características conforme as ideologias que comportam, as profissões e os trabalhos que executam e até mesmo as tradições étnicas que herdam. A este respeito, vale a contribuição de Erving Goffman quando afirma que entre a realidade concreta objetiva e os espaços individuais das subjetividades há uma zona comum, uma mediação que ocorre a partir da linguagem e das memórias públicas 
evocadas. Este espaço imaginário seria então recheado de "identidades virtualizadas" que são construídas pelos sujeitos em sociedade, mantidas, reproduzidas e impostas previamente no cotidiano. Parafraseando o autor, a sociedade estabelece meios de categorizar as pessoas, imputando-lhes atributos que não precisam corresponder necessariamente à realidade, mas que são construções sociais "virtuais", expectativas normativas que constroem identidades sociais no imaginário coletivo e que são impostas politicamente às pessoas ${ }^{1}$.

Este fenômeno, que antecede o surgimento dos espaços online, vem sendo estudado por muitos pesquisadores nas últimas décadas em temáticas que variam da inclusão social de pessoas com deficiência ${ }^{2}$, o convívio e sociabilidade de alunos e/ou grupos específicos no ambiente escolar ${ }^{3}$, até a construção socializada da ideia de "minorias" e suas implicações na cotidianidade ${ }^{4}$. Recentemente, o que parece diferir com o surgimento dos espaços online é a inclusão de um novo elemento a este processo que é a plena abstração dos sujeitos - a guerra agora é antes entre avatares que nas ruas. Neste sentido, alguns autores já apontaram a permanência deste fenômeno nas redes, uma vez que estas mesmas identidades virtuais não desapareceram e participam constitutivamente desta dinâmica relacional promovida por estes novos ambientes de comunicação mediada ${ }^{5}$.

Ora, assim sendo, ser de esquerda ou de direita, ou ser professor ou militar, neste imaginário coletivo que está sendo diariamente construído e socializado, parece significar um combo, um conjunto coerente de ações, pensamentos, posicionamentos, gostos, hábitos, propensões, valores, costumes, crenças, que estruturam um eixo de características inegociáveis, um modo permanente de viver. Em vista disso, exatamente por uma característica automaticamente subentender as demais neste universo das redes, esses espaços computadorizados estão aprofundando as distâncias entre as pessoas, fragilizando - no âmbito discursivo e imaginário - a própria convivência democrática.

Mas, será que realmente estes estereótipos socializados, estas identidades virtuais, correspondem na integralidade às características de pessoas reais? Será que no âmbito da cognição as pessoas são coerentes com essas projeções sociais e apresentam simultaneamente esta combinação de características e posicionamentos? Será que uma característica/identificação subentende e pressupõe outras características/identificações? Para responder a essas questões precisaríamos de uma pesquisa sobre as correlações das ideias históricas no interior da cognição com a geração de ações práticas no mundo. Por se tratar do enfrentamento desses estereótipos populares com os seus variados posicionamentos práticopolíticos, pesquisas quantitativas podem trazer muitas contribuições neste sentido, dada a 
natureza dos diagnósticos macros. Contudo, esta seria ainda uma pesquisa por fazer. Por ora, o projeto já desenvolvido e aplicado, coordenado pelo professor Dr. Luis Fernando Cerri, junto ao Grupo de Estudos em Didática da História (GEDHI), intitulado "Projeto Residente: Observatório das relações entre jovens, história e política na América Latina"6, pode nos auxiliar neste início de investigação por ser um grande diagnóstico de posicionamentos políticos, tomadas de decisões e ideias históricas de jovens latino-americanos. Podemos aqui isolar algumas das assinalações desses jovens e buscar correlações, o que nos possibilita um início de investigação sobre esta possível relação entre os estereótipos populares e os múltiplos posicionamentos, comportamentos e ideias históricas dos jovens.

O Projeto Residente é atual, interinstitucional e internacional que envolve pesquisadores de diversas cidades do Brasil e de seis outros países da América Latina. Consiste num survey intercultural e quantitativo que coletou opiniões e posicionamentos políticos de 5991 jovens de 15 a 16 anos. No Brasil, onde ocorreu a maior coleta, a pesquisa buscou contemplar escolas públicas e privadas e abarcou vinte e quatro cidades ${ }^{7}$, distribuídas em oito estados, com destaque para a prevalência dos estados do Paraná e Bahia, o que possibilitou uma amostra nacional de 3923 jovens. Esta coleta ocorreu entre março e setembro do ano de 2019, na forma de questionário online. Professores da rede e colaboradores do projeto participaram deste processo de aplicação e abastecimento do Software.

A maioria das questões do projeto foram elaboradas com base na escala Likert (com cinco graus de variações nas respostas $)^{8}$ e envolveram temas variados: de práticas docentes e questões relacionadas ao ambiente escolar (diagnóstico de metodologias, relação com os livros didáticos, participação política na escola) à valoração da História, interesse por temas, questões polêmicas do tempo presente, projeções de futuro e identificações com a regionalidade.

\section{O software, a sistematização dos dados e a proposta de correlação das ideias e posicionamentos.}

O Projeto Residente decorre de duas outras experiências recentes de pesquisa na região, Jovens brasileiros e argentinos diante da história (2007) e Projeto Jovens e a História no Mercosul (2012), que juntos vêm acumulando reflexões teórico-metodológicas no estudo da cognição e da cultura histórica ${ }^{9}$. Nestes trabalhos, dois softwares estão sendo bastante utilizados na sistematização dos dados: o Software GNU PSPP e o Software SPSS StatisticsIBM. Das formas de análises preferidas por estes pesquisadores temos as médias Likert, os 
dados de frequência (número real de assinalação), os índices de porcentagem, as tabelas cruzadas e a recente utilização da bússola política ${ }^{10}$.

Neste momento, utilizando o Software SPSS Statistics-IBM (v.22), o que pretendemos é acrescentar uma outra forma de visualizar dados de grandes amostras e a partir disso incorporar ao debate metodológico, especialmente, as discussões que versam sobre a utilização da bússola política. Não trabalharemos com as médias que decorrem das assinalações, como muito se tem feito em pesquisas nacionais, pois escolhemos apresentar um processo inverso: em meio à amostra nacional, isolar os indivíduos e verificar suas assinalações múltiplas e simultâneas, que exprimem ideias correlacionadas, para depois retornar à visão do todo com um diagnóstico das semelhanças.

Como procuramos contrastar estereótipos do senso comum com os dados empíricos, a partir de uma observação prévia em inúmeros comentários de postagens na rede social do Facebook $^{11}$, identificamos três possíveis perfis de estereótipos que rondam as representações públicas dos sujeitos que participam/participaram dos movimentos de rua de espectro político liberal-conservador. Estas características e suas relações foram extraídas dos comentários que teceram críticas a estes indivíduos.

Reconhecemos a fragilidade destas correlações, ou suas incoerências, mas esta constatação não diminui a sua eficácia prática em meio aos jogos e discussões políticas que ocorrem nestes espaços. Por isso, julgamos que estes perfis precisam ser aproximados com dados empíricos e, para isso, propositalmente invertemos aqui a lógica dos estudos quantitativos, que costumam construir perfis somente a partir dos resultados que decorrem dos dados e seus cruzamentos. De modo inverso, assumiremos hipoteticamente a existência destes perfis, tal como imaginam e correlacionam as críticas dos comentadores nas redes sociais, para depois verificarmos a intensidade de suas correspondências nos dados do Projeto Residente. Seguem os perfis abaixo:

Tabela 1: Três possíveis estereótipos

Nacionalistas Individualistas-conservadores Defensores da família

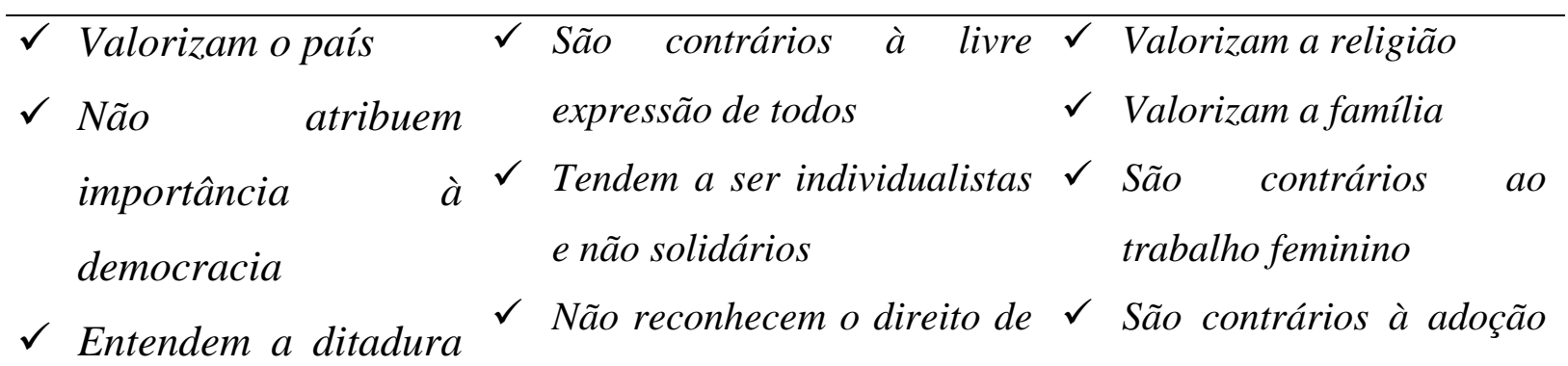




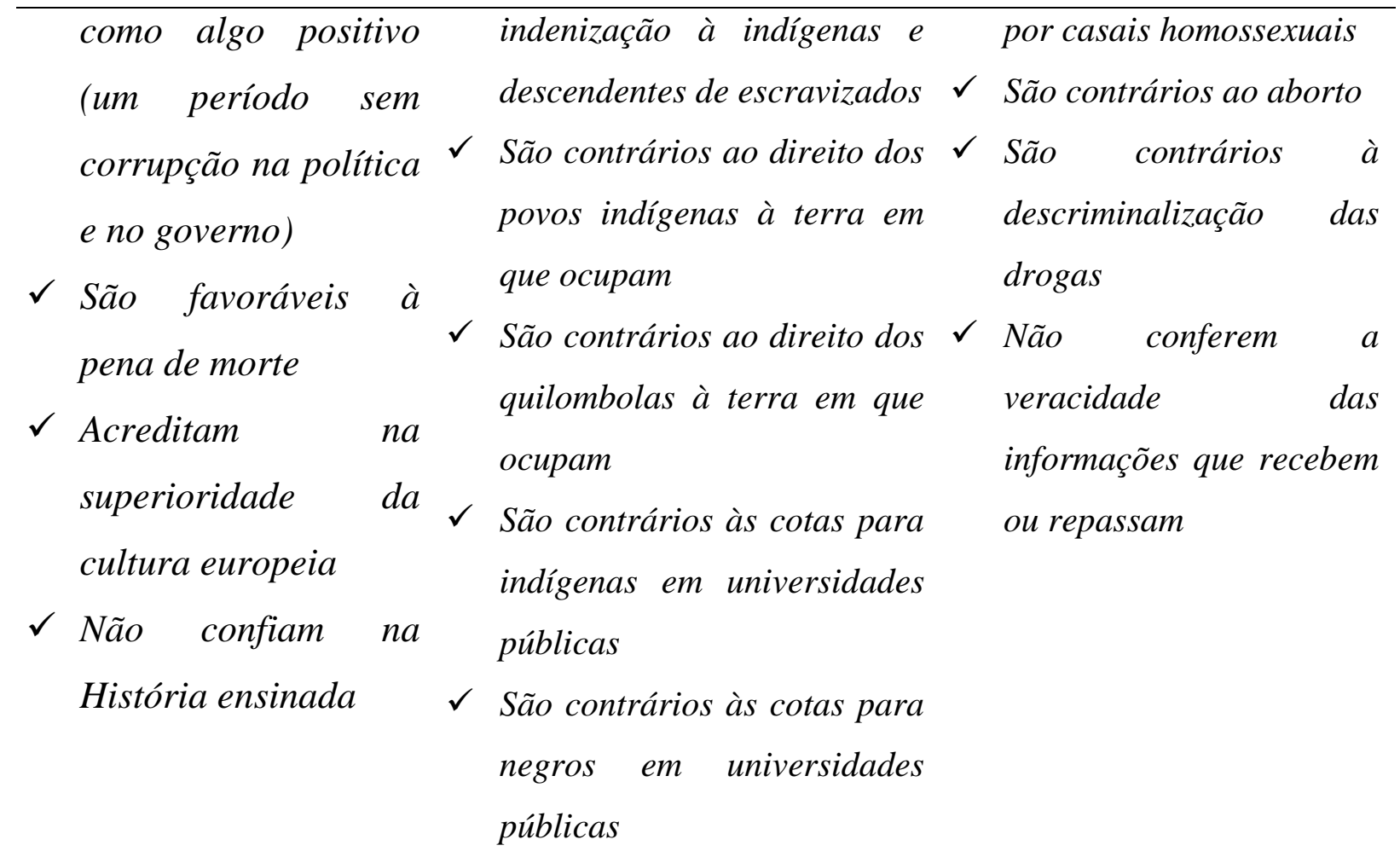

Fonte: O Autor (2021).

Como dissemos, são representações generalistas e estereotipadas, que, por serem assim, cabem em qualquer coisa e nada ao mesmo tempo. Estamos atentos a isso. Logo, um refinamento possível destes três estereótipos poderia decorrer da análise de autoidentificações, que neste momento escapa ao escopo do texto.

Ainda, nos dias atuais, há um outro agravante que é a tomada conjunta destas características destes estereótipos para se referir ao avanço do fascismo enquanto ideologia. Aí temos um rótulo que se sobrepõe a estes perfis que já são deficitários em suas definições. Ou seja, um conceito complexo que vem se tornando sinônimo destes perfis generalistas nas redes sociais. No momento, não estamos preocupados em formular corretamente o fascismo ou em constatar o seu avanço na sociedade brasileira, o que demandaria outra pesquisa. Por ora, o que nos preocupa é como este conceito vem sendo esticado nas redes sociais junto a estes estereótipos o que acaba por separar as pessoas em sociedade. O mesmo poderíamos dizer das expressões "esquerdistas" e "comunistas", igualmente problemáticas e polissêmicas, vulgarmente utilizadas politicamente nestes mesmos espaços. Porém, como se percebe, os três perfis indicados se enquadram nas críticas exageradas que normalmente são atribuídas à militantes ou indivíduos politicamente alinhados à direita, se formos considerar o sistema de 
caracterização do espectro político. Esta seleção de perfis é proposital, demonstra nossa intenção de diálogo e crítica interna.

Como meio a se alcançar estas correlações de posicionamentos utilizamos a técnica das tabelas cruzadas do software, que comporta até 7 inter-relações e que isola os jovens e demonstra as suas assinalações simultâneas. Estas múltiplas tabelas não estarão disponíveis neste texto, mas segue um exemplo abaixo que demonstra os cruzamentos de duas alternativas e suas assinalações extremas, como "nenhuma" ou "total", que escolhemos isolar e analisar neste texto por representar especificamente a parcela dos jovens que se posicionam acreditando estar na sua maior certeza.

Tabela 2: Exemplo: Correlação entre atribuição de importância à democracia e o posicionamento sobre a reserva de vagas à indígenas nas universidades.

\begin{tabular}{|c|c|c|c|c|c|c|}
\hline & & $\begin{array}{c}34.5 \text { Reserva de } \\
\text { discordo } \\
\text { totalmente }\end{array}$ & $\begin{array}{l}\text { as para índios } \\
\text { discordo }\end{array}$ & $\begin{array}{l}\text { as universidades } \\
\text { nem concordo } \\
\text { nem discordo }\end{array}$ & $\begin{array}{l}\text { icas é, em gera } \\
\text { concordo }\end{array}$ & $\begin{array}{l}\text { ma boa ideia } \\
\text { concordo } \\
\text { totalmente }\end{array}$ \\
\hline \multirow{5}{*}{ 21.8 Democracia } & nenhuma importância & 32 & 27 & 71 & 60 & 45 \\
\hline & pouca importância & 25 & 41 & 131 & 135 & 51 \\
\hline & importância média & 36 & 78 & 329 & 283 & 163 \\
\hline & muita importância & 46 & 87 & 262 & 365 & 212 \\
\hline & importância total & 46 & 74 & 205 & 325 & 355 \\
\hline
\end{tabular}

Fonte: Projeto Residente (2019) - Adaptado de Software SPSS Statistics - IBM. Total: 3484.

Assim, indicamos aqui algumas das questões que nos conduzem na interpretação destes dados: é possível que alguém manifeste todas as características listadas nos perfis ao mesmo tempo? Estas combinações de características encontram respaldo total ou razoável nos dados empíricos do Projeto Residente? E se estas combinações inexistirem, quais destas ideias ou posicionamentos teriam alguma ou maior correlação no imaginário popular de acordo com a amostra?

\section{Resultado preliminar e correlações de ideias e posicionamentos.}

Antes de cogitarmos as correlações, precisamos saber se isoladamente cada uma daquelas características e posicionamentos extremos que compõem os perfis foram assinaladas pelos jovens de nossa amostra. Assim, temos o seguinte panorama geral de assinalações conforme os perfis (as alternativas escolhidas e analisadas do projeto Residente estão todas dispostas abaixo): 
Tabela 3 - Número de jovens que assinalaram os posicionamentos mais extremos em características isoladas que compõem os perfis (Amostra: 3923 jovens)

\begin{tabular}{|c|c|c|}
\hline \multicolumn{3}{|r|}{ Nacionalistas } \\
\hline $\begin{array}{l}N^{\circ} \text { de } \\
\text { jovens }\end{array}$ & $\begin{array}{l}\% \text { do } \\
\text { total }\end{array}$ & Alternativas do Projeto Residente \\
\hline 1374 & $35 \%$ & O meu país (importância total) \\
\hline 801 & $20,4 \%$ & A pena de morte deveria existir para a maioria dos crimes hediondos (concorda totalmente) \\
\hline 548 & $14 \%$ & $\begin{array}{l}\text { (Governos militares) Um período sem corrupção na política e no governo (concorda } \\
\text { totalmente) }\end{array}$ \\
\hline 257 & $6,5 \%$ & Democracia (nenhuma importância) \\
\hline 203 & $5,17 \%$ & $\begin{array}{l}\text { A contribuição das culturas indígenas é equivalente às culturas europeias na formação do } \\
\text { nosso país (discorda totalmente) }\end{array}$ \\
\hline 153 & $3,9 \%$ & $\begin{array}{l}\text { A contribuição das culturas negras é equivalente às culturas europeias na formação do } \\
\text { nosso país (discorda totalmente) }\end{array}$ \\
\hline 117 & $2,98 \%$ & Falas dos professores (confia muito pouco) \\
\hline
\end{tabular}

\begin{tabular}{|c|c|c|}
\hline \multicolumn{3}{|r|}{ Individualistas-conservadores } \\
\hline $\begin{array}{l}\mathbf{N}^{\circ} \text { de } \\
\text { jovens }\end{array}$ & $\begin{array}{l}\% \text { do } \\
\text { total }\end{array}$ & Alternativas do Projeto Residente \\
\hline 435 & $11,08 \%$ & $\begin{array}{l}\text { Ninguém. Não se deve reconhecer o direito a essa indenização (Indenizações à indígenas e/ } \\
\text { ou descendentes de escravos. Quem deveria pagar?) }\end{array}$ \\
\hline 287 & $7,31 \%$ & $\begin{array}{l}\text { Povos indígenas tem direito à propriedade do território em que viveram seus ancestrais } \\
\text { (discorda totalmente) }\end{array}$ \\
\hline 247 & $6,29 \%$ & $\begin{array}{l}\text { Comunidades de negros que escaparam da escravidão (quilombos) têm direito à } \\
\text { propriedade da terra que tradicionalmente ocupam (discorda totalmente) }\end{array}$ \\
\hline 222 & $5,65 \%$ & $\begin{array}{l}\text { Reserva de vagas para negros nas universidades públicas é, em geral, uma boa ideia } \\
\text { (discorda totalmente) }\end{array}$ \\
\hline 195 & $4,97 \%$ & $\begin{array}{l}\text { Reserva de vagas para índios nas universidades públicas é, em geral, uma boa ideia } \\
\text { (discorda totalmente) }\end{array}$ \\
\hline 122 & & Liberdade de opinião para todos (nenhuma importância) \\
\hline 99 & $2,44 \%$ & Solidariedade com os pobres do meu país (nenhuma importância) \\
\hline
\end{tabular}

Defensores da família

\begin{tabular}{|c|c|c|}
\hline \multirow[b]{2}{*}{$\begin{array}{c}\mathbf{N}^{\circ} \text { de } \\
\text { jovens }\end{array}$} & \\
\hline & $\begin{array}{l}\% \text { do } \\
\text { total }\end{array}$ & Alternativas do Projeto Residente \\
\hline 2700 & $68,8 \%$ & Família (importância total) \\
\hline 1491 & $38 \%$ & É muito importante (religião) \\
\hline 1190 & $30,3 \%$ & (Informações novas) Cada um tem a sua verdade \\
\hline 669 & $17 \%$ & $\begin{array}{l}\text { A posse de maconha para uso pessoal não deve ser considerada um crime (discorda } \\
\text { totalmente) }\end{array}$ \\
\hline 632 & $16,11 \%$ & $\begin{array}{l}\text { O aborto, nos casos em que a vida da mulher não está ameaçada, deve ser sempre ilegal } \\
\text { (concorda totalmente) }\end{array}$ \\
\hline 361 & $9,2 \%$ & $\begin{array}{l}\text { Um casal do mesmo sexo em uma relação amorosa estável não deveria ser excluído da } \\
\text { possibilidade de adotar uma criança (discorda totalmente) }\end{array}$ \\
\hline 179 & $4,56 \%$ & $\begin{array}{l}\text { As mães podem ter carreiras profissionais, mas seu principal dever é o de ser donas de casa } \\
\text { (concorda totalmente) }\end{array}$ \\
\hline
\end{tabular}

Fonte: Projeto Residente (2019) - Adaptado de Software SPSS Statistics - IBM. Total: 3923.

Quando observamos individualmente podemos constatar que as características que listamos para os perfis encontram significativa correspondência com as assinalações dos jovens. Ou seja, por mais extrema que seja a alternativa ou o posicionamento, os dados empíricos demonstram a existência de simpatizantes. Destes dados, família, religião e país 
foram as temáticas com os maiores índices de assinalações (de "importância total"), que representaram, inclusive, de $35 \%$ até $68,8 \%$ da amostra nacional total. Na sequência, com $30,3 \%$, temos as expressivas assinalações de relatividade do conhecimento (leia-se não procuro conferir com especialistas a veracidade do conhecimento que recebo, pois cada um tem a sua própria verdade); depois a defesa da pena de morte, com 20,4\%; e a discórdia com a descriminalização da posse da maconha para o uso pessoal, com 17\%. Assim, se aproximarmos as características dos três perfis, das menores assinalações extremas para as maiores, percebemos que as alternativas com maior expressividade na opinião dos jovens apontam para um interstício de temas que mesclam substancialmente pautas da moralidade, nacionalismo e religiosidade.

Quando observamos os menores índices de assinalações por perfil, podemos assumir este valor como o limite máximo hipotético de jovens que tenham assinalado todas as alternativas ao mesmo tempo para compor o perfil estereotípico. Assim, a previsão matemática nos possibilitaria algo em torno de $2,98 \%$ da amostra total com correspondência integral ao primeiro perfil, $2,44 \%$ com relação ao segundo e 4,56\% ao terceiro. O que já nos indica previamente a possível prevalência do terceiro perfil (Defensores da família), seguido do primeiro (Nacionalistas) e depois do segundo (Individualistas-conservadores). Evidentemente, esta estatística é válida apenas se analisarmos estes perfis isoladamente, já que nada impede de uma mesma pessoa acumular as características destes perfis. Este seria o cenário hipotético com o maior grau de correspondência possível, o que por si só já é um dado significativo por serem índices baixos e contrastarem com a vulgaridade e o tom generalista das representações virtuais.

Contudo, longe desta previsão encontrar correspondência nos dados empíricos do Projeto, o resultado dos cruzamentos apresentou $0 \%$ de jovens que tenham assinalado ao mesmo tempo todas as alternativas necessárias para compor cada um dos perfis. Assim, a présuposição de que este conjunto de características fossem integralmente correlacionadas, no modo mais extremo, e que um posicionamento pudesse subentender os demais, não encontrou embasamento em nossa amostra. Mesmo todas estas alternativas tendo sido significativamente assinaladas (conforme se visualiza na Tabela 2), não significou que foram assinaladas todas ao mesmo tempo, pelos mesmos indivíduos, conforme os perfis estabelecidos.

Assim, passamos então para o nosso próximo momento de investigação. Se estes perfis radicais não existem na integralidade em nossa amostra, será que existem parcialmente? 
Podemos responder a esta questão observando como se comporta a variação no número de jovens nos perfis conforme se inserem gradativamente as alternativas no software. Observamos abaixo:

Tabela 4 - Variação no número de jovens nos perfis conforme se inserem gradativamente as alternativas no Software SPSS Statistics - IBM ${ }^{12}$.

\section{NACIONALISTAS}

\section{ALTERNATIVAS DO PROJETO RESIDENTE}

I. O meu país (importância total)

II. A pena de morte deveria existir para a maioria dos crimes hediondos (concorda totalmente)

III. (Governos militares) Um período sem corrupção na política e no governo (concorda totalmente)

$I V$. Democracia (nenhuma importância)

$V$. A contribuição das culturas indígenas é equivalente às culturas europeias na formação do nosso país (discorda totalmente)

VI. A contribuição das culturas negras é equivalente às culturas europeias na formação do nosso país (discorda totalmente)

VII. Falas dos professores (confia muito pouco)

\begin{tabular}{cccc}
\hline $\mathbf{N}^{\circ}$ de Jovens & \% do total & \% de redução & Assinalações simultâneas \\
\hline $\mathbf{1 3 7 4}$ & $35 \%$ & & I \\
$\mathbf{3 5 1}$ & $8,94 \%$ & $74,4 \%$ & I + II \\
$\mathbf{1 0 9}$ & $2,78 \%$ & $69,9 \%$ & I + II + III \\
$\mathbf{1 3}$ & $0,33 \%$ & $88 \%$ & I + II + III + IV \\
$\mathbf{2}$ & $0,05 \%$ & $84,6 \%$ & I + II + III + IV + V \\
$\mathbf{1}$ & $0,02 \%$ & $50 \%$ & I + II + III + IV + V + VI \\
$\mathbf{0}$ & $0 \%$ & & I + II + III + IV + V + VI + VII \\
\hline
\end{tabular}

\section{INDIVIDUALISTAS-CONSERVADORES}

\section{ALTERNATIVAS DO PROJETO RESIDENTE}

I. Ninguém. Não se deve reconhecer o direito a essa indenização. (Indenizações à indígenas e/ ou descendentes de escravos. Quem deveria pagar?)

II. Reserva de vagas para negros nas universidades públicas é, em geral, uma boa ideia (discorda totalmente)

III. Reserva de vagas para índios nas universidades públicas é, em geral, uma boa ideia (discorda totalmente)

$I V$. Comunidades de negros que escaparam da escravidão (quilombos) têm direito à propriedade da terra que tradicionalmente ocupam (discorda totalmente)

$V$. Povos indígenas tem direito à propriedade do território em que viveram seus ancestrais (discorda totalmente)

VI. Liberdade de opinião para todos (nenhuma importância)

VII. Solidariedade com os pobres do meu país (nenhuma importância)

\begin{tabular}{cccc}
\hline $\mathbf{N}^{\circ}$ de Jovens & \% do total & \% de redução & Assinalações simultâneas \\
\hline $\mathbf{4 3 5}$ & $11,1 \%$ & & I \\
$\mathbf{7 7}$ & $1,96 \%$ & $82,3 \%$ & I + II \\
$\mathbf{4 9}$ & $1,25 \%$ & $36,4 \%$ & I + II + III \\
$\mathbf{1 8}$ & $0,46 \%$ & $63,3 \%$ & I + II + III + IV \\
$\mathbf{9}$ & $0,23 \%$ & $50 \%$ & I + II + III + IV + V \\
$\mathbf{0}$ & $0 \%$ & & I + II + III + IV + V + VI \\
$\mathbf{0}$ & $0 \%$ & & I + II + III + IV + V + VI + VII \\
\hline
\end{tabular}


I. Família (importância total)

II. É muito importante (religião)

III. (informações novas) Cada um tem a sua verdade

$I V$. O aborto, nos casos em que a vida da mulher não está ameaçada, deve ser sempre ilegal. (concorda totalmente)

$V$. A posse de maconha para uso pessoal não deve ser considerada um crime. (discorda totalmente)

VI. Um casal do mesmo sexo em uma relação amorosa estável não deveria ser excluído da possibilidade de adotar uma criança. (discorda totalmente)

VII. As mães podem ter carreiras profissionais, mas seu principal dever é o de ser donas de casa (concorda totalmente)

\begin{tabular}{cccc}
\hline $\mathbf{N}^{\circ}$ de Jovens & \% do total & \% de redução & Assinalações simultâneas \\
\hline $\mathbf{2 7 0 0}$ & $68,8 \%$ & & I \\
$\mathbf{1 1 8 6}$ & $30,23 \%$ & $56 \%$ & I + II \\
$\mathbf{3 7 8}$ & $9,63 \%$ & $68,1 \%$ & I + II + III \\
$\mathbf{8 6}$ & $2,2 \%$ & $77,2 \%$ & I + II + III + IV \\
$\mathbf{3 1}$ & $0,8 \%$ & $63,9 \%$ & I + II + III + IV + V \\
$\mathbf{4}$ & $0,1 \%$ & $87 \%$ & I + II + III + IV + V + VI \\
$\mathbf{0}$ & $0 \%$ & & I + II + III + IV + V + VI + VII \\
\hline
\end{tabular}

Fonte: Projeto Residente (2019) - Adaptado de Software SPSS Statistics - IBM. Total: 3923.

Em termos quantitativos, podemos seguramente apontar as interrelações do perfil Defensores da Família como as mais expressivas, onde se verifica que aproximadamente 10\% da amostra total assinalou as três primeiras alternativas do perfil ao mesmo tempo, o que é bastante significativo se compararmos com os demais perfis. A alternativa de importância total à família, mais a de importância total à religião e a relatividade do conhecimento parece ser a combinação de maior intensidade e expressividade em termos quantitativos. Outra relação de destaque quantitativo diz respeito ao perfil Nacionalistas e sua primeira interrelação, que aproximou a alternativa de importância total ao país à de concordância com a pena de morte, uma união que encontrou respaldo em quase $9 \%$ da amostra total.

Agora, quando seguimos na busca pela parcialidade dos estereótipos, podemos constatar que os perfis começam a ser identificados em nossos dados a partir de seis interrelações para o primeiro $(0,02 \%$ da amostra total) e o terceiro perfil $(0,1 \%)$, e cinco interrelações para o segundo $(0,23 \%)$, o que novamente nos sugere ser o perfil Individualistas-conservadores o de maior dificuldade em assumir todas as características propostas.

Assim, seja num perfil ou noutro, parece haver características e/ou posicionamentos que quando inseridos como opção no software, os perfis deixam de existir na totalidade, nos demonstrando um possível limite em suas aproximações. À exemplo, quando observamos o primeiro perfil, Nacionalistas, que previamente sugeria e relacionava nacionalismo, apreço à ditadura, descrença na democracia e a não confiança na História ensinada, o que se percebe é que a inclusão deste último posicionamento impossibilita a sua total fundamentação em 
nossos dados. O mesmo ocorre com o último perfil e a inclusão da concordância sobre o papel da mulher, e do segundo perfil e a inclusão tanto da discórdia da liberdade da opinião de todos, quanto da não importância da solidariedade com os pobres do país. Ora, neste momento, é importante atentarmos a evolução dos dados conforme dispostos na tabela acima para nos afastarmos de conclusões precipitadas acerca do peso destes últimos posicionamentos, que são significativos, mas vale observarmos que há decréscimos também significativos de jovens com as alternativas anteriores.

Vejamos, no perfil Nacionalistas, dentre a maior assinalação do grupo (alternativa I) e a maior combinação deste grupo (I + II) houve um decréscimo de mais de mil jovens. Ou seja, concordar totalmente com a pena de morte é um significativo ponto de discórdia entre os 1374 jovens que atribuem importância total ao país. Com este decréscimo, que chega a ser de $74,4 \%$, os jovens que sobram sofrem novo decréscimo logo na segunda combinação de maior significância (I + II + III) de 69\%, passando de 351 para 109 jovens. Quer dizer, neste perfil, quanto mais avançamos na procura pelo estereótipo, mais deixamos para trás um recorte bastante considerável da amostra. Dos 351 jovens que articularam no pensamento importância total ao país e defesa da pena de morte, apenas 31\% deles (109 jovens) também articularam o entendimento e defesa dos governos militares como não corruptos. Tendo feito este alerta, quando se encontra o estereótipo, que passa a existir de seis combinações para menos, vale considerarmos a significativa proporção que não está contemplada em seus valores e que assim compõem a complexidade da manifestação da cognição histórica em sociedade.

Se até aqui identificamos as alternativas com os maiores índices de frequência (assinalações), neste momento observar este percentual de decréscimo que ocorre com as inclusões das alternativas no software, nos parece ser uma possível maneira de visualizarmos o potencial de proximidade entre elas no imaginário popular (decréscimos com percentuais elevados poderiam estar nos significando altos índices de rechaço à proximidade entre essas ideias e posicionamentos, e o inverso também pode ser considerado, decréscimos com percentuais baixos podem nos indicar significativas possibilidades/potencialidades de aproximação).

Assim, após termos cruzado todas as alternativas dos perfis entre si no Software e diagnosticado seus percentuais de decréscimos, listamos abaixo as três ideias/posicionamentos que mais se aproximam por perfil e as três ideias/posicionamentos que menos se aproximam. O sentido da flecha indica o sentido do decréscimo, por exemplo, de todos os jovens que assinalaram que a Ditadura Militar foi um período sem corrupção, 
quando isolamos estes jovens e observamos quantos destes também assinalaram a alternativa que atribuía importância total ao país, percebemos que os $100 \%$ iniciais decresceram $52,4 \%$. Este índice de decréscimo é significativo, porém é expressivamente menor que quando

Tabela 5 - As três relações com os menores índices de decréscimos (proximidades que julgamos mais significativas) e as três relações com os maiores índices de decréscimos (proximidades que julgamos menos significativas) para cada um dos perfis. Fonte: Projeto Residente (2019) - Adaptado de Software SPSS Statistics - IBM. Total: 3923.

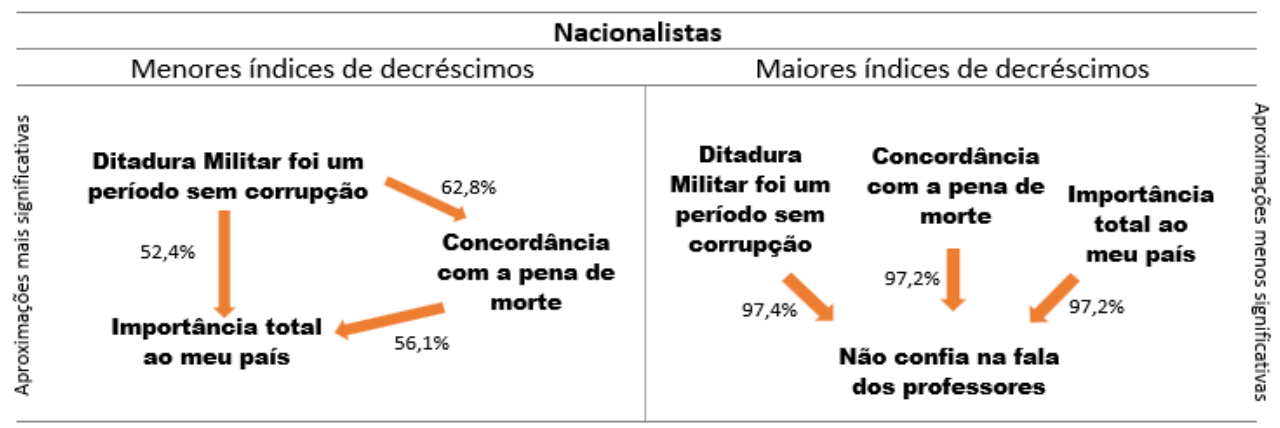

Individualistas-conservadores

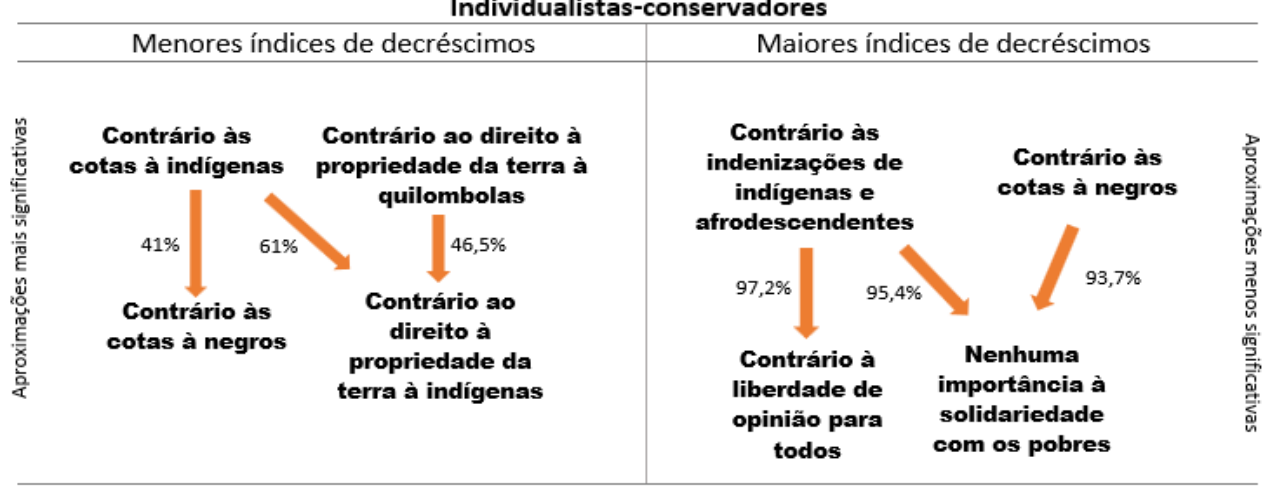

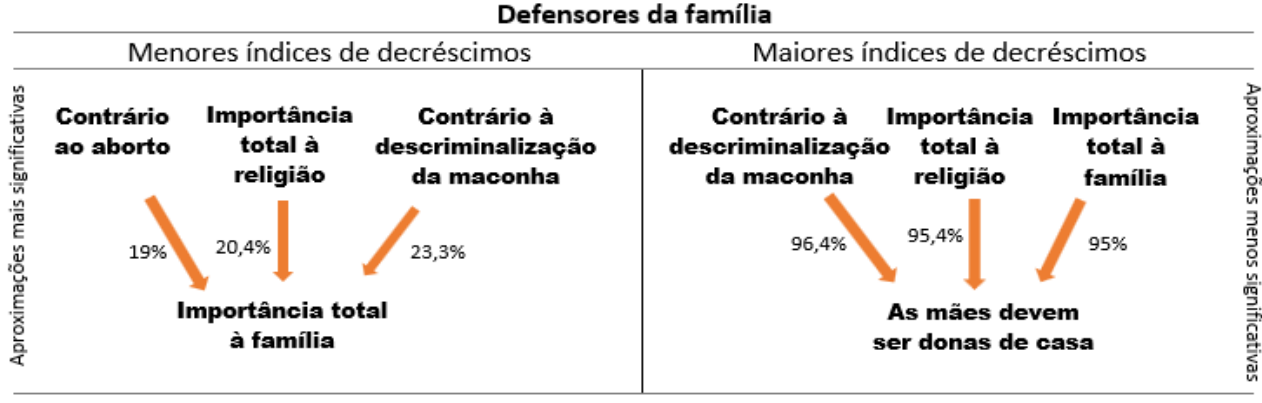

observamos quantos destes mesmos jovens iniciais assinalaram a alternativa que se referia a desconfiança na fala dos professores, em que tivemos a diminuição de 97,4\%. Diante desses mínimos e desses máximos encontrados, estamos aqui propondo como hipótese que estas manifestações empíricas, em alguma medida, estejam exprimindo estas mesmas aproximações ou distanciamentos no interior da cultura histórica. Pesquisadores futuros 
podem trilhar este caminho de investigação no estudo destas relações nos espaços culturais de formação das ideias históricas.

Com esta tabela podemos perceber que as características listadas para cada um dos perfis não se aproximam entre si de modo igual, com graus semelhantes ou previsíveis de correlação. Pelo contrário, os perfis hipotéticos listados demostram posicionamentos internos que se contrapõem significativamente em nossa amostra.

Por exemplo, no perfil Nacionalistas, a partir da consideração dos menores decréscimos, podemos propor que no imaginário popular há uma aproximação mais significativa entre os posicionamentos acerca da Ditadura Militar, pena de morte e valorização do país, formando uma espécie de núcleo mais sólido do perfil, enquanto que estas mesmas três características se distanciam significativamente do posicionamento sobre a desconfiança total com relação à fala dos professores de História. Curiosamente, para mais de $97 \%$ deste perfil, não há uma relação direta entre o posicionamento de descrença total na História ensinada com estes três posicionamentos radicais, esta é uma informação emblemática tendo visto os inúmeros ataques que os professores de História vêm sofrendo publicamente desde 2013, que decorrem de inúmeras estratégias políticas de setores organizados da sociedade.

No perfil Individualistas-conservadores o núcleo mais sólido identificado diz respeito à aproximação de apenas dois posicionamentos: contrariedade com relação às cotas universitárias à negros e indígenas e contrariedade com relação ao direito à terra para quilombolas e indígenas. Este segundo perfil tem a ver com as dimensões da individualidade e coletividade humana e a capacidade dos sujeitos demonstrarem empatia em pautas sociais. Aqui, o cenário de disputa parece evocar nos sujeitos o princípio da individualidade, critério que precisa conviver e se reajustar com os próprios valores da moralidade. Evidentemente, estamos lidando com decisões políticas de jovens de nossa amostra num momento já consolidado do neoliberalismo na região, que em alguma medida reflete sobre seus posicionamentos enquanto ideologia, que apontamos aqui como um possível modus operandi da consciência. Privacidade, individualismo, liberdade e sucesso econômico formariam uma espécie de filtro conjunto de visão e de interpretação da realidade, a partir das memórias recuperadas, que se constituem como interesses com os quais os jovens possivelmente avaliaram as alternativas deste questionário.

Numa entrevista ao canal Jornalistas Livres ${ }^{13}$, a filósofa e professora Marilena Chauí realizou uma discussão sobre como as políticas neoliberais refletem nos indivíduos como ideologia neoliberal. Para a autora, esta ideologia se apresenta como uma estratégia de 
convencimento que emana das práticas neoliberais (em especial, a transformação dos direitos sociais em serviços/mercadorias). Desse modo, cria-se na sociedade a ideia de que a privatização dos serviços e direitos sociais é algo bom. Esta construção, que se encontra num momento avançado em nossa sociedade, remodela a ideia que o indivíduo tem de si próprio, de tal forma que ele não se vê mais como pertencente a uma classe social (como trabalhador), mas através de uma imagem idealizada de "empresário de si próprio", que presta serviços e negocia em condições de igualdade com o empregador. Faz parte desta ideologia a ideia de que o indivíduo arque com o ônus de saúde, previdência, educação e formação individual para que se torne mais atraente no mercado, ideia que se alinha a um individualismo extremado, o qual desobriga o Estado de suas responsabilidades a partir da ilusão da meritocracia: o indivíduo constrói a si mesmo, investe em si mesmo, perde a referência de classe ao se projetar numa ilusão de consumo e se relaciona socialmente a partir de uma lógica individualista competitiva.

Se assim for, podemos inferir que esta ligação entre a ideologia liberal e os posicionamentos dos jovens se mostra visível neste núcleo contrário às políticas de reajuste social, possivelmente, por serem políticas que no imaginário popular destoam da lógica do mérito, do esforço individual, do sucesso de "si próprio" e da não intervenção do Estado, já que deste modo o Estado estaria destacando e privilegiando grupos específicos. Interessante é percebermos como este núcleo do perfil Individualistas-conservadores se distancia significativamente dos posicionamentos radicais acerca da não liberdade de opinião para todos e da não solidariedade com os pobres do país. Ou seja, os mesmos jovens que se posicionaram contra estas políticas de reajuste social não se manifestaram totalmente intolerantes com relação a estes outros dois posicionamentos. Possivelmente, uma contradição não percebida no interior da cognição que decorre de um entendimento não processual da História, uma vez que estas memórias carregadas de ideologias costumam não trazer em suas narrativas os processos históricos que constroem e mantém a pobreza enquanto fenômeno histórico-social em nosso país, como também os movimentos de luta que historicamente disputam os espaços no interior da democracia. Ou seja, neste repositório de memórias neoliberais, a pobreza vira questão de falta de esforço e a democracia passa a ser compreendida como o local/palco da não contradição.

Já no último perfil, Defensores da família, temos o núcleo mais sólido dentre os três perfis, com a destoante e baixa ordem aproximada de $20 \%$ de distância entre os posicionamentos: contrariedade ao aborto, descriminalização das drogas, importância total à 
religião e importância total à família. Por ser este o perfil com os maiores índices de frequência, e tendo ainda encontrado este conjunto de características nucleares com alto poder de correlação/proximidade, podemos afirmar ser esta uma característica simbólica da amostra nacional do Projeto Residente e que convém ser considerada pelos próximos pesquisadores em pesquisas futuras. Sabemos que esta amostra não tem um potencial estatístico para corresponder e representar toda a realidade dos jovens brasileiros, mas se o caso nacional, em alguma medida, também refletir este núcleo encontrado, estaríamos lidando com a permanência de uma cultura que sabidamente antecede as últimas eleições - dada a história promíscua de nosso país que tradicionalmente relaciona valores religiosos, instituições religiosas e políticas públicas -, mas que, vale destacar, foi exaustivamente instrumentalizada pelos candidatos em suas campanhas no processo eleitoral de 2018 , que, em alguma medida estaria aqui refletindo em nossos dados. Em torno da instituição abstrata "família", os candidatos fabricaram um cenário hipotético de crise a partir da triangulação de temas como aborto, homossexualidade e drogadição. "Família" e "Religião" seriam os pilares a serem defendidos diante destes ataques supostamente inéditos, uma cruzada religiosa eleitoral que se deu na direção de salvaguardar a "verdadeira" família brasileira e os seus valores cristãos.

Ainda, também destoando do tom vulgar das representações populares da rede de internet, este núcleo encontrado no perfil Defensores da Família se distancia significativamente do posicionamento acerca do papel das mulheres, em especial das mães, no que se refere ao direito ao trabalho. Ser religioso, defensor da família e/ou contrário à descriminalização das drogas não significou, para 95\% dos jovens, aceitar o trabalho doméstico como uma obrigação materna e única forma de trabalho que cabe às mulheres ${ }^{14}$. Isso nos sugere, inclusive, como o direito ao trabalho às mulheres já é uma questão bastante consolidada no interior destes grupos, inclusive dos mais religiosos. Uma questão a ser observada futuramente é como este índice de 5\% pode vir a variar nos próximos anos.

Por fim, avançando para a nossa última reflexão, convém indicarmos aqui a possibilidade destes dados do Projeto Residente caracterizarem também os três perfis pelo não critério da intensidade. Assim, não observando mais as assinalações extremas, como escolhemos fazer para constatar os estereótipos, identificamos abaixo a maior combinação possível de jovens em cada um dos perfis em suas assinalações livres e múltiplas. 
Tabela 6 - Maiores combinações possíveis de jovens por perfis e suas características

NACIONALISTAS (16 JOVENS)

\begin{tabular}{|c|c|c|c|c|c|}
\hline \multicolumn{6}{|c|}{ Escala de intensidade } \\
\hline \multirow[t]{8}{*}{ Nenhum } & Pouco & Médio & Grande & Total & Alternativas do Projeto Residente \\
\hline & & & $\mathrm{X}$ & & O meu país (Grau de Importância) \\
\hline & & & $\mathrm{X}$ & & A pena de morte deveria existir para a maioria dos crimes hediondos (Grau de concordância) \\
\hline & & $\mathrm{X}$ & & & $\begin{array}{l}\text { (Governos militares) Um período sem corrupção na política e no governo (Grau de } \\
\text { concordância) }\end{array}$ \\
\hline & & $\mathrm{X}$ & & & $\begin{array}{l}\text { A contribuição das culturas indígenas é equivalente às culturas europeias na formação do } \\
\text { nosso país (Grau de concordância) }\end{array}$ \\
\hline & & $\mathrm{X}$ & & & Democracia (Grau de Importância) \\
\hline & & $\mathrm{X}$ & & & $\begin{array}{l}\text { A contribuição das culturas negras é equivalente às culturas europeias na formação do nosso } \\
\text { país (Grau de concordância) }\end{array}$ \\
\hline & & & $\mathrm{X}$ & & Falas dos professores (Grau de confiança) \\
\hline
\end{tabular}

\section{INDIVIDUALISTAS-CONSERVADORES (78 JOVENS)}

\begin{tabular}{|c|c|c|c|c|c|}
\hline \multicolumn{6}{|c|}{ Escala de intensidade } \\
\hline \multirow[t]{10}{*}{ Nenhum } & Pouco & Médio & Grande & Total & Alternativas do Projeto Residente \\
\hline & & & & & $\begin{array}{l}\text { Os países colonizadores que se beneficiaram da exploração } \\
\text { (Indenizações à indígenas e/ ou descendentes de escravos. Quem deveria pagar?) }\end{array}$ \\
\hline & & & & $\mathrm{X}$ & $\begin{array}{l}\text { Povos indígenas tem direito à propriedade do território em que viveram seus ancestrais (Grau } \\
\text { de concordância) }\end{array}$ \\
\hline & & & & $\mathrm{X}$ & $\begin{array}{l}\text { Comunidades de negros que escaparam da escravidão (quilombos) têm direito à propriedade } \\
\text { da terra que tradicionalmente ocupam (Grau de concordância) }\end{array}$ \\
\hline & & & & $\mathrm{X}$ & $\begin{array}{l}\text { Reserva de vagas para negros nas universidades públicas é, em geral, uma boa ideia (Grau de } \\
\text { concordância) }\end{array}$ \\
\hline & & & & $\mathrm{X}$ & $\begin{array}{l}\text { Reserva de vagas para índios nas universidades públicas é, em geral, uma boa ideia (Grau de } \\
\text { concordância) }\end{array}$ \\
\hline & & & & $\mathrm{X}$ & Liberdade de opinião para todos (Grau de Importância) \\
\hline & & & & $\mathrm{X}$ & Solidariedade com os pobres do meu país (Grau de Importância) \\
\hline & \multicolumn{5}{|c|}{ DEFENSORES DA FAMÍLIA (23 JOVENS) } \\
\hline & \multicolumn{5}{|c|}{ Escala de intensidade } \\
\hline \multirow[t]{8}{*}{ Nenhum } & Pouco & Médio & Grande & Total & Alternativas do Projeto Residente \\
\hline & & & & $\mathrm{X}$ & Família (Grau de Importância) \\
\hline & & & & & $\begin{array}{l}\text { (Informações novas) Verifico se tem base em fontes confiáveis e na opinião dos historiadores } \\
\text { e professores de História }\end{array}$ \\
\hline & & & & $\mathrm{X}$ & Religião (Grau de Importância) \\
\hline & $\mathrm{X}$ & & & & $\begin{array}{l}\text { A posse de maconha para uso pessoal não deve ser considerada um crime. (Grau de } \\
\text { concordância) }\end{array}$ \\
\hline & & & $\mathrm{X}$ & & $\begin{array}{l}\text { O aborto, nos casos em que a vida da mulher não está ameaçada, deve ser sempre ilegal. } \\
\text { (Grau de concordância) }\end{array}$ \\
\hline & & & $\mathrm{X}$ & & $\begin{array}{l}\text { Um casal do mesmo sexo em uma relação amorosa estável não deveria ser excluído da } \\
\text { possibilidade de adotar uma criança (Grau de concordância) }\end{array}$ \\
\hline & $X$ & & & & $\begin{array}{l}\text { As mães podem ter carreiras profissionais, mas seu principal dever é o de ser donas de casa } \\
\text { (Grau de concordância) }\end{array}$ \\
\hline
\end{tabular}

Fonte: Projeto Residente (2019) - Adaptado de Software SPSS Statistics - IBM. Total: 3923.

Mesmo com uma amostra de 3923 jovens, convém destacarmos aqui o baixo índice de expressividade de cada um dos perfis quando manifestado livremente: Nacionalistas (16 jovens / 0,4\% da amostra total), Individualistas-conservadores (78 jovens / 2\% da amostra total) e Defensores da Família (23 jovens / 0,6\% da amostra total). Ou seja, se anteriormente procuramos os estereótipos e seus posicionamentos radicais e encontramos os baixos índices respectivos de $0,02 \%, 0,23 \%$ e $0,1 \%$, quando avançamos para a procura do número máximo de jovens em suas expressões livres acerca dos temas, novamente constatamos índices pouco 
expressivos, abaixo de $2 \%$ da amostra total. Esta dupla averiguação nos sugere que a amostra do Projeto Residente é muito mais diversa e complexa do que poderíamos propor, ou que imaginavam os comentadores das redes virtuais. Se o maior grupo de jovens que se assemelharam em suas manifestações políticas foi este de $2 \%$, podemos inferir que os demais $98 \%$ se recombinam em meio às variadas alternativas das questões por perfil numa infinidade de grupos ainda menores que se expressam abaixo destes $2 \%$. Este baixo diagnóstico de semelhanças nos leva a mais algumas indagações para pesquisas futuras: a) a escolha metodológica de aproximar sete posicionamentos políticos estaria naturalmente limitando as formações de grupos e aproximações entre os jovens? Caso tivéssemos escolhido outras sete questões do Projeto, estes baixos índices de semelhanças teriam se repetido?; b) Esta dificuldade em encontrar jovens com os mesmos sete posicionamentos políticos se repetiria caso escolhêssemos repartir a amostra nacional do Projeto em cidades, gênero, classe social ou religiosidades?; c) Em que medida esta constatação da pluralidade desafia as teorias e explicações pedagógicas do aprendizado histórico que buscam aproximar consciência e cultura histórica?

Agora, retornando para a tabela 5, constatamos que entre o representado inicialmente pelos estereótipos e estas manifestações livres dos jovens, temos significativas zonas de proximidades e zonas de divergências nos perfis Nacionalistas e Defensores da Família. Em outras palavras, o "ser" nacionalista ou defensor da família é um "ser" que parcialmente corresponde ao seu estereótipo, ao mesmo tempo em que comporta algumas contradições significativas.

Vejamos, o perfil Nacionalistas foi o que uniu o maior número de posicionamentos intermediários, que podem ser lidos como índices de neutralidade, intensidade média ou abstenções (que decorrem de escolhas conscientes ou do desconhecimento destes jovens com relação aos temas propostos). Neste conjunto estariam as alternativas acerca do entendimento do período do regime militar, a valoração da cultura negra e indígena em relação a cultura europeia na formação do povo brasileiro e a importância do regime democrático. Deixando de lado a possibilidade destes índices médios serem escolhas conscientes de intensidade, podemos atentar ao quão perigoso caldo cultural formam estas alternativas caso estes 16 jovens realmente desconheçam estes assuntos ou se abstenham em refletir e assinalar com maior assertividade, ficando assim suscetíveis aos atuais discursos elitistas e ideológicos de propaganda de desvalorização da cultura nacional e do povo brasileiro, de ufanismo retrógrado em relação aos tempos da Ditadura Militar, e da representação midiática diária que 
constrói uma caricatura negativa da democracia a partir de seus infinitos exemplos de casos de corrupção e de representação insultuosa dos movimentos sociais. Ora, o que gostaríamos de destacar é que acreditamos ser o posicionamento neutro um campo facilmente em disputa pelas forças políticas da sociedade, portanto, no campo metodológico, uma constatação carregada de provisoriedade. Ainda, observando a composição deste perfil, estes quatro posicionamentos neutros se somam à significativa valorização do país e da pena de morte posicionamentos que compuseram o núcleo mais sólido de seu estereótipo - e, também, da fala dos professores de História (único posicionamento que destoou deste estereótipo). Assim, podemos indicar ser este um perfil com potencialidade a corresponder ao seu estereótipo, dependendo possivelmente do momento histórico e das forças políticas em jogo. Noutras palavras, o "ser" nacionalista estereotípico está a espreita, podendo ser mobilizado com maior intensidade - leia-se correspondência ao estereótipo - em possíveis cenários futuros. Por ora, o que se encontrou deste perfil foram sentimentos neutros, ou vagos, sobre as contribuições culturais de negros e indígenas ao povo brasileiro, sobre o que foi o período da Ditadura Militar e a atual democracia brasileira, que se mescla a um sentimento de valorização do país e vontade de implementação da pena de morte.

O perfil Defensores da Família se assemelhou ao seu estereótipo a partir da valorização total da família e total da religião, da concordância com a criminalização das drogas (leia-se maconha) e da discordância com relação ao aborto. Dentre os três perfis, foi o que mais se assemelhou ao seu estereótipo, contrastando apenas no referido ao direito à adoção por casais homossexuais, ao entendimento do trabalho doméstico e do papel da mulher (leia-se mães) e por não afirmarem a relatividade do conhecimento histórico (já que assinalaram que buscam conferir a veracidade das informações históricas que recebem com historiadores e professores). Ou seja, esta verificação pode ser entendida como um reflexo dos tempos transitórios em que vivemos, onde dogmas e ideias centrais do patriarcado parecem conviver com pautas progressistas no interior da cognição. Uma constatação que, talvez, poderia ser interpretada como uma possível contradição, uma causalidade, se fosse identificada nos grupos minoritários do perfil. Mas não foi o que ocorreu, esta foi a combinação que resultou do grupo mais expressivo no interior do perfil, o que nos sugere que, no interior da amostra do Projeto, relacionar religião, família, adoção para casais homossexuais e o posicionamento favorável com relação ao trabalho feminino é estatisticamente superior à possível relação religião, família, contrariedade ao direito à adoção por casais homossexuais e a defesa da exclusividade do trabalho doméstico às mulheres. 
Podemos então afirmar que, para esta amostra, estes são dois pontos ditos não "tradicionais" que atualmente convivem com as anteriores pautas "tradicionais" diagnosticadas, dois pontos que destoaram significativamente da representação estereotípica.

Por fim, destoando dos anteriores, o perfil Individualistas-conservadores se manifestou integralmente como a expressão do oposto de sua representação estereotípica, numa significativa proporção 8,6 para $1^{15}$. Ou seja, na amostra do Projeto, para cada jovem que se enquadrou parcialmente no perfil hipotético Individualistas-conservadores, temos 8,6 jovens que se enquadraram exatamente no oposto desta representação, sendo a maior combinação de jovens para este perfil. Esta é uma informação que nos traz otimismo dado o tom generalista das redes que atualmente replicam dados e exemplos reacionários por parte dos jovens com relação às políticas de ajuste social. A manifestação livre deste perfil se demonstrou altamente solidária com a causa negra e indígena (tanto ao direito à terra, como às políticas de cotas), ao mesmo tempo em que demonstrou solidariedade para com os pobres do país e defesa da democracia no que se refere à liberdade de opinião à todas as pessoas. Contudo, ao direcionarem o pagamento desta dívida histórica com relação aos negros e indígenas aos países colonizadores - leia-se Portugal -, uma questão que nos fica é saber como estes jovens deste grupo estão interpretando as atuais elites brasileiras, suas históricas e atuais relações de subserviência ao capital imperialista, e suas internas políticas de manutenção do poder via a conservação das condições sociais, culturais e econômicas das classes trabalhadoras. Ora, se as atuais elites brasileiras e classes políticas forem abstidas desta responsabilidade histórica estaríamos diante de um empasse no interior da cognição, onde se reconhece a dignidade, a necessidade e a urgência destas pautas sociais, mas não os sujeitos atuais que, em alguma medida, estariam mantendo esta estrutura injusta e que também precisam ser responsabilizados neste processo.

\section{Considerações finais.}

Diante de uma escrita um tanto densa, porém necessária, convém aqui aproximar as principais conclusões do texto.

Percebemos que todas as características radicais listadas previamente para os estereótipos encontraram correspondência na amostra do Projeto Residente, mas com dificuldades em compor integralmente os perfis. Parcialmente, estes perfis se apresentaram estatisticamente abaixo dos $0,23 \%$ da amostra total. 
Diante desta constatação, percebemos que em cada um dos perfis tivemos núcleos mais sólidos de relações entre os posicionamentos, assim como também encontramos posicionamentos e características que destoaram significativamente. Expressivamente, a amostra apresentou dois eixos estruturantes: a) união significativa entre os jovens que assinalaram ao mesmo tempo importância total à família, importância total à religião e a relatividade do conhecimento; b) união entre os jovens que assinalam importância total ao país e defenderam a pena de morte.

Por fim, quando abrimos mão desta procura pelas assinalações de maior intensidade, conforme as opções da escala Likert, e passamos a observar os dados em suas manifestações espontâneas de graduação, o que encontramos foram estes mesmos núcleos de características para os perfis Nacionalistas e Defensores da Família - sendo o primeiro o perfil mais suscetível a possíveis intervenções da cultura, e o segundo o mais numericamente expressivo dentre os três -, mas que não ocorreu no caso do perfil Individualistas-conservadores, que se manifestou exatamente o oposto de sua representação virtual. Além disso, esta observação livre sobre as assinalações dos jovens também nos demonstrou a complexidade da relação consciência-cultura, já que o que se constatou não foi uma uniformidade de pensamentos e posicionamentos, mas antes uma diversidade tão expressiva de grupos que o próprio diagnostico estatístico se tornou desnecessário, sendo a totalidade da amostra uma infinidade de sub-grupos minúsculos que se assemelham entre si, e os poucos grupos que se destacaram numericamente alcançaram o índice máximo de $2 \%$ da amostra total.

\section{Notas}

\footnotetext{
${ }^{1}$ GOFFMAN, Erving. Estigma: notas sobre a manipulação da identidade deteriorada. Rio de Janeiro: LTC, 2012, p. 12.

${ }^{2}$ MAGALHÃES, Rita de Cássia Barbosa; CARDOSO, Ana Paula Lima. A pessoa com deficiência e a crise das identidades na contemporaneidade, Cadernos de Pesquisa, v. 40, p. 45-61, 2010; SILVA, Marcos Antonio Carneiro da; MONTEIRO, Diogo Hersen. Entre as normalidades e as anormalidades: Os possíveis estigmas atribuídos aos estudantes considerados portadores do TDAH, nas escolas municipais do Rio de Janeiro, Educação, Sociedade e Culturas, n. 57, p. 145-163, 2020.

${ }^{3}$ MASCARENHAS, Maíra. Simmel e Goffman: contribuições para o estudo das relações sociais no ambiente escolar, Revista Intratextos, v.4, n.1, p. 240-257, 2012; NASCIMENTO, Manoel Alves do. Erving Goffman, as interações no cotidiano escolar, desvendando o estigma dentro da inclusão escolar. 2009. 137 f. Dissertação (Mestrado em Educação) - Universidade Metodista de São Paulo, São Bernardo do Campo, 2009.

${ }^{4}$ OLIVEIRA, Vanessa Florêncio de. O racismo como uma "identidade social virtual", Revista Sem Aspas, v. 7 , n. 2, p. 283-291, 2018.; PRADO, Francieli Muller. M.; Marivânia de Araujo. Estigma: a construção da identidade dos 'flanelinhas'. In: IX ENCONTRO INTERNACIONAL DE PRODUÇÃO CIENTÍFICA UNICESUMAR, 2015, Maringá. Anais de Eventos. Maringá: IX EPCC, 2015.

${ }^{5}$ RIBEIRO, José Carlos. Múltiplas identidades virtuais: a potencialização das experiências exploratórias do "eu". Contracampo, n.12, p. 171-184, 2005; SANT'ANNA, Paula Soares. Autorretratos em identidades virtuais: a
} 
experiência selfie. 2016. Dissertação (Mestrado em Memória Social) - Universidade Federal do Rio de Janeiro, Rio de Janeiro, 2016; SILVA, Admilson Veloso da. et al.. A Construção da Identidade Virtual nos Sites de Relacionamentos. In: INTERCOM - SOCIEDADE BRASILEIRA DE ESTUDOS INTERDISCIPLINARES DA COMUNICAÇÃO XIV CONGRESSO DE CIÊNCIAS DA COMUNICAÇÃO NA REGIÃO SUDESTE, 2009, Rio de Janeiro. Disponível em: < http://www.intercom.org.br/papers/regionais/sudeste2009/resumos/R140932-1.pdf>. Acesso em: 23/10/2021.

${ }^{6} \mathrm{O}$ projeto Residente é a segunda experiência de aplicação nacional, por parte do grupo GEDHI. Anteriormente, o projeto se intitulou "Jovens e a História" e coletou 2240 questionários, de 22 cidades brasileiras no ano de 2012. Estes dois projetos estão disponíveis em: https://www2.uepg.br/gedhi/, acessado em 25/11/2020.

${ }^{7}$ Eunápolis (BA), Cachoeira (BA), Feira de Santana (BA), Vitória da Conquista (BA), Governador Mangabeira (BA), Muritiba (BA), Morrinhos (GO), Diamantina (MG), Uberlândia (MG), Rio de Janeiro (RJ), Nova Iguaçu (RJ), São Paulo (SP), Prudentópolis (PR), Londrina (PR), Jacarezinho (PR), Inajá (PR), Arapongas (PR), Ponta Grossa (PR), Piraí do Sul (PR), Curitiba (PR), Guarapuava (PR), Foz do Iguaçu (PR), Papanduva (SC), Porto Alegre (RS).

8 "Escala Likert (cinco níveis variando de péssimo a ótimo, discordo totalmente a concordo totalmente e assim por diante), a partir da qual se atribui valores numéricos a cada resposta (de -2 para a resposta mais negativa, passando por zero para as respostas neutras e 2 para a resposta mais positiva), sendo que o tratamento é a produção de médias que permitem ver a concordância média com cada afirmação, e a definição de desvio padrão, que permite conhecer a média da variação das respostas" (CERRI; COUDANNES, 2011, p. 127). Método desenvolvido por Rensis Likert (1903 - 1981), professor de sociologia, psicologia e diretor do Instituto de Pesquisas Sociais de Michigan. A escala Likert foi apresentada à comunidade científica na publicação "A Technique for the Measurement of Attitudes" (VIERIA; DALMORO, 2008).

${ }^{9}$ Disponíveis em: https://www2.uepg.br/gedhi/, acessado em 25/11/2020.

${ }^{10}$ ALVEZ, F.; CERRI, L. F., 2009; AMÉZOLA, G.; CERRI, L. F., 2008; CUESTA, V.; LINARE, C, 2014; GARRIGA, M. C.; PAPPIER, V.; MORRAS, V, 2010; GONZALEZ, M. P, 2010; MISTURA, L.; CAIMI, F. E, 2013; PACIEVITCH, C, 2016; CRUZ, M. M, 2019.

11 Para listarmos estas características observamos os comentários de inúmeras postagens das páginas de Facebook "Esquerda Revolucionária 2.0", "Notícias UOL", "Haddad debochado" e "Soldadinho de chumbo", durante os meses de novembro e dezembro de 2020. Estes três perfis hipotéticos foram criados tentando respeitar e aproximar as interrelações de sentido empreendidas pelos usuários comentadores. Da lista de características, adjetivações e expressões encontradas, aproximamos o máximo de sete qualidades/atributos por perfil, conforme a potencialidade máxima de cruzamento do Software SPSS Statistics IBM (v2.0). Tomamos a liberdade de nomear estes perfis conforme estas suas características encontradas.

${ }^{12}$ Esta tabela resulta da melhor combinação entre as alternativas que compõem cada perfil. Todas as alternativas foram cruzadas com todas as alternativas e esta sequência disposta por perfil demostra a ordem encontrada a se alcançar este maior número de jovens.

${ }^{13}$ Disponível em: <http://migre.me/w07p9>. Acesso em: 05/02/2017.

${ }^{14} \mathrm{O}$ decréscimo registrado entre a alternativa referente à contrariedade do aborto e a concordância com a exclusividade do dever das mães para com o lar foi de $88,6 \%$. Ou seja, dos jovens que concordaram com a proibição irrestrita ao aborto, $88,6 \%$ não assinalaram ao mesmo tempo a opção referente ao dever das mães. Portanto, uma distância também significativa entre estes dois posicionamentos.

${ }^{15}$ Esta proporção resulta da razão entre os valores encontrados para o perfil Individualistas-conservadores: 9 jovens no estereótipo parcial (ver tabela 3 ) e 78 jovens nas assinalações livres.

\section{Referências}

ALVEZ, Federico; CERRI, Luís Fernando. Ensenanza de historia reciente en Uruguay: pasado y laicidad en el juego de la identidad. Archivos de Ciencias de la Educación, La Plata, v. 3, n. 3, p. 99-112, 2009.

AMÉZOLA, Gonzalo; CERRI, Luís Fernando. La historia del tiempo presente en las escuelas de Argentina y Brasil. Revista HISTEDBR, Campinas, n. 32, p. 4-16, 2008. 
CERRI, Luís Fernando. Dados quantitativos na reflexão didática de estudantes e professores de História. Revista História Hoje, São Paulo, v. 5, n. 10, p. 138-158, 2016.

CERRI, Luís Fernando; COUDANNES, Mariela. Jovens e sujeitos da História. Estudos Ibero-Americanos, Porto Alegre, v. 37, n. 1, p. 125-140, jan./jun. 2011.

CHAUI, Marilena. A tragédia liberal e a meritocracia. Entrevista. Canal Jornalistas Livres. Disponível em: <http://migre.me/w07p9>. Acessado em: 29 de jan. de 2021.

CRUZ, Matheus Mendanha. Posicionamento Político, Conhecimento Histórico e Pensamento Utópico: Uma Análise Com Dados Quantitativos De Jovens Dos Campos Gerais/Pr - 2017. Araucaria: Revista iberoamericana de filosofía, politica y humanidades, v. 21, p. 187-208, 2019.

CUESTA, Virgínia; LINARE, Cecília. La enseñanza y el aprendizaje de la Historia desde la mirada de los jóvenes en el cono Sur. In: XV JORNADAS NACIONALES Y IV INTERNACIONALES DE ENSEÑANZA DE LA HISTORIA APEHUN, 2014.

GARRIGA, Maria Cristina; PAPPIER, Viviana; MORRAS, Valéria. Los jóvenes entre la historia y la política. Primeras aproximaciones a las representaciones de la democracia, los gobiernos militares y la participación política de alumnos de la escuela secundaria. Revista Clio \& Associados, Santa Fe/La Plata, n. 14, p. 1-10, 2010.

GEDHI: Grupo de Estudos em Didática da História, 2021. Página inicial. Disponível em: <https://www2.uepg.br/gedhi/>. Acessado em: 29 de jan. de 2021.

GOFFMAN, Erving. Estigma: notas sobre a manipulação da identidade deteriorada. Rio de Janeiro: LTC, 2012.

GONZALEZ, Maria Paula. Los jóvenes y la historia en la perspectiva de profesores de Brasil, Argentina y Uruguay, Clío \& Asociados. La Historia Enseñada, Santa Fe/La Plata, n. 14, p. 152-166, 2010.

MAGAlHÃES, Rita de Cássia Barbosa; CARDOSO, Ana Paula Lima. A pessoa com deficiência e a crise das identidades na contemporaneidade, Cadernos de Pesquisa, v. 40, p. 45-61, 2010.

MASCARENHAS, Maíra. Simmel e Goffman: contribuições para o estudo das relações sociais no ambiente escolar, Revista Intratextos, v.4, n.1, p. 240-257, 2012.

MISTURA, Letícia; CAIMI, Flávia Eloisa. Herói, ainda que tardio: uma análise do ensino da história sobre o mito de Tiradentes, Revista Latino-Americana de História, v. 2, n. 6, 2013.

NASCIMENTO, Manoel Alves do. Erving Goffman, as interações no cotidiano escolar, desvendando o estigma dentro da inclusão escolar. 2009. 137 f. Dissertação (Mestrado em Educação) - Universidade Metodista de São Paulo, São Bernardo do Campo, 2009.

OLIVEIRA, Vanessa Florêncio de. O racismo como uma "identidade social virtual", Revista Sem Aspas, v. 7, n. 2, p. 283-291, 2018. 
PACIEVITCH, Caroline. Esquerda ou direita? Professores, opção política e didática da história. In: SIMPÓSIO NACIONAL DE HISTÓRIA, 28, 2015, Florianópolis. Anais... Florianópolis: UFSC, 2015. Disponível em:

<http://www.snh2015.anpuh.org/resources/anais/39/1427419415_ARQUIVO_Anpuh2015Te xtocompleto.pdf $>$. Acesso em: 13/11/2016.

PRADO, Francieli Muller. M.; Marivânia de Araujo. Estigma: a construção da identidade dos 'flanelinhas'. In: IX ENCONTRO INTERNACIONAL DE PRODUÇÃO CIENTÍFICA UNICESUMAR, 2015, Maringá. Anais de Eventos. Maringá: IX EPCC, 2015.

RIBEIRO, José Carlos. Múltiplas identidades virtuais: a potencialização das experiências exploratórias do "eu". Contracampo, n.12, p. 171-184, 2005.

SANT'ANNA, Paula Soares. Autorretratos em identidades virtuais: a experiência selfie. 2016. Dissertação (Mestrado em Memória Social) - Universidade Federal do Rio de Janeiro, Rio de Janeiro, 2016.

SILVA, Marcos Antonio Carneiro da; MONTEIRO, Diogo Hersen. Entre as normalidades e as anormalidades: Os possíveis estigmas atribuídos aos estudantes considerados portadores do TDAH, nas escolas municipais do Rio de Janeiro, Educação, Sociedade e Culturas, n. 57, p. 145-163, 2020.

SILVA, Admilson Veloso da. et al.. A Construção da Identidade Virtual nos Sites de Relacionamentos. In: INTERCOM - SOCIEDADE BRASILEIRA DE ESTUDOS INTERDISCIPLINARES DA COMUNICAÇÃO XIV CONGRESSO DE CIÊNCIAS DA COMUNICAÇÃO NA REGIÃO SUDESTE, 2009, Rio de Janeiro. Disponível em: < http://www.intercom.org.br/papers/regionais/sudeste2009/resumos/R14-0932-1.pdf>. Acesso em: 23/10/2021.

VIEIRA, Kelmara Mendes; DALMORO, Marlon. Dilemas na construção de escalas tipo Likert: o número de itens e a disposição influenciam nos resultados?. In: XXXII ENCONTRO DA ANPAD, 2008, Rio de Janeiro. Disponível em: <http://www.anpad.org.br/admin/pdf/EPQ-A1615.pdf>. Acesso em: 27/12/2016. 